\title{
Efficacy and Safety of Travoprost and Timolol Fixed Combination Compared to Travoprost in Patients with Primary Open Angle Glaucoma and Ocular Hypertension
}

\author{
Gentian Hoxha ${ }^{1}$, Kelmend Spahiu' ${ }^{1}$, Gazmend Kaçaniku' ${ }^{1}$, Mimoza Ismaili ${ }^{1}$, Fëllanza Ismajli-Hoxha ${ }^{2}$ \\ ${ }^{1}$ Department of Ophthalmology, Faculty of Medicine, University Clinical Center of Kosovo, Prishtina, Kosovo \\ ${ }^{2}$ Department of Dermatovenerology, Faculty of Medicine, University Clinical Center of Kosovo, Prishtina, Kosovo \\ Email: gentianhoxha@gmail.com
}

How to cite this paper: Hoxha, G., Spahiu, K., Kaçaniku, G., Ismaili, M. and IsmajliHoxha, F. (2017) Efficacy and Safety of Travoprost and Timolol Fixed Combination Compared to Travoprost in Patients with Primary Open Angle Glaucoma and Ocular Hypertension. Open Journal of Ophthalmology, 7, 176-183.

https://doi.org/10.4236/ojoph.2017.73024

Received: April 29, 2017

Accepted: July 14, 2017

Published: July 17, 2017

Copyright $\odot 2017$ by authors and Scientific Research Publishing Inc. This work is licensed under the Creative Commons Attribution International License (CC BY 4.0).

http://creativecommons.org/licenses/by/4.0/

\begin{abstract}
Purpose: To compare intraocular pressure (IOP)-lowering efficacy and safety of travoprost $0.004 \%$ and travoprost $0.004 \%$ and beta-blocker $0.5 \%$ fixed combination ophthalmic solution in patients with open-angle glaucoma and ocular hypertension. Methods: In this prospective, multicentre clinical trial, 62 patients received travoprost $0.004 \%(n=31)$ or travoprost $0.004 \%$ and beta-blocker $0.5 \%$ fixed combination $(\mathrm{n}=31)$. Efficacy and safety were compared across treatment groups over 2 years. IOP reduction and adverse events were examined at 3, 6, 12 and 24 months for each group. Results: Mean IOP at the first visit in the travoprost $0.004 \%$ group was $26.4(\mathrm{SD} \pm 2.1)$, and travoprost $0.004 \% /$ timolol $0.5 \%$ group was 26.3 ( $\mathrm{SD} \pm 2.1$ ). Mean IOP after 24 months in the travoprost $0.004 \%$ group was $20.5(\mathrm{SD} \pm 1.5)$ and travoprost $0.004 \% /$ timolol $0.5 \%$ group was 18.5 ( $\mathrm{SD} \pm 1.5$ ). There were statistically significant differences in IOP in both eyes after third visit (after 1 year) and fourth visit (after 2 years). Conclusion: After 2 year of treatment, travoprost $0.004 \% /$ timolol $0.5 \%$ produced clinically relevant IOP reductions in patients with open-angle glaucoma or ocular hypertension that were greater than those produced by travoprost $0.004 \%$ alone.
\end{abstract}

\section{Keywords}

Open Angle Glaucoma, Ocular Hypertension, Travoprost/Timolol Fixed Combination, Adverse Event

\section{Introduction}

Glaucoma is a common and potentially blinding ocular disease of multifactorial 
etiology. It is characterized by progressive acquired loss of retinal ganglion cells leading to optic nerve atrophy and visual field deficits. An estimated 60.5 million people would have open angle and angle closure glaucoma by 2010, increasing to 79.6 million by 2020 [1]. Elevated intraocular pressure (IOP) is an important and modifiable risk factor for the development and progression of glaucoma [2]. Primary open angle glaucoma (POAG) is a chronic optic neuropathy that can lead to blindness if untreated [3].

Drugs play a frontline role in IOP reduction in glaucoma and for years, $\beta$-blockers are the leading medicines in use because of their capacity to slow the rate of aqueous humour production [4]. In the European Union and elsewhere, the prostaglandin analogue class of IOP-lowering drugs has become the most commonly used first-line drug class for the treatment of elevated IOP in patients with open-angle glaucoma or ocular hypertension. Many patients will require more than one medication to achieve IOP targets and beta-blockers are commonly used as adjunctive therapy to prostaglandin analogues in patients requiring a multi-drug regimen [5] [6] [7] [8].

Intraocular pressure is an important risk factor for the development and progression of glaucoma. In recent years, The Ocular Hypertension Treatment Trial has demonstrated that IOP reduction can prevent the development of glaucoma among individuals with ocular hypertension and can reduce the risk of glaucoma progression among subjects with both normal and elevated IOP [9] [10].

The impact of both short-term and long-term IOP variability on progression risk has also been explored, with many studies [11] [12] [13] finding a positive relationship between greater IOP variability and higher rates of glaucomatous progression or development.

The aim of the study was to compare intraocular pressure (IOP)-lowering efficacy and safety of travoprost $0.004 \%$ and travoprost $0.004 \%$ and beta-blocker $0.5 \%$ fixed combination ophthalmic solution in patients with open-angle glaucoma and ocular hypertension. The novelty of this study was the long period of treatment over 2 years with same ophthalmic eye drops without switching to another one.

\section{Materials and Methods}

We conducted a randomized, open prospective multicenter study in which two groups were treated in parallel. We studied 62 patients ( 29 female and 33 male) diagnosed with primary open angle glaucoma or ocular hypertension. Patients with primary open angle glaucoma and ocular hypertension receiving monotherapy with travoprost $0.004 \%$ or travoprost $0.004 \% /$ timolol $0.5 \%$ fixed combination were included in this study.

The diagnostic criteria of the primary open angle glaucoma and ocular hypertension is decided after goniscopy, examination of optic nerve head and retinal nerve fiber layer and perimetry. Visual field testing is important for the diagnosis of glaucoma, and even more important for follow-up and management of glaucoma. 
Subjects who fulfilled the diagnostic criteria and did not meet the exclusion criteria were followed-up for 2 years. A single drop of travoprost $0.004 \%$ or travoprost $0.004 \% /$ timolol $0.5 \%$ fixed combination was instilled into the conjunctival sac of one or both eyes of the patients once a day.

The exclusion criteria were as follows: history of hypersensitivity to $\beta$-blockers or conditions where $\beta$-blockers are contraindicated (e.g., bronchial asthma, inadequately controlled cardiac failure); concurrent, chronic or recurrent uveal inflammation, scleral inflammation, or corneal herpes; history of ocular trauma, internal eye surgery within 3 months before the baseline examination; difficulty in undergoing applanation tonometry; use of corticosteroid ophthalmic solution; serious ocular complication; pregnant or lactating women; and severe dementia.

Potential subjects who met the inclusion criteria received sufficient explanation regarding the study and information concerning the treatment according to the principles of the Declaration of Helsinki. Written informed consent was obtained from all patients included in the study.

IOP was measured using Goldmann applanation tonometer for each eye between 8 a.m. and 10 a.m. at baseline (day 0) and four control visits: control 1 (after 3 months), control 2 (after six months), control 3 (after 1 year) and control 4 (after 2 years).

The data processing is done with the statistical package SPSS 22.0. From statistical parameters are calculated index structure, arithmetic mean and standard deviation.

Testing of qualitative data is done with $\mathrm{X}^{2}$ test or Fisher's test while testing of quantitative data with T-test or Mann-Whitney test. Verification testing is done with reliability of $95 \%(\mathrm{P}<0.05)$.

\section{Results}

In this study were included 62 patients with POAG or ocular hypertension. Patients were divided in two groups, 31 in travoprost $0.004 \%$ group and other 31 in fixed combination travoprost $0.004 \% /$ timolol $0.5 \%$.

In travoprost $0.004 \%$ group $45.2 \%$ or 14 patients were females while in fixed combination, females were $48.4 \%$ or 15 .

Since in two groups, men were more than women, there was no statistically significant difference between the genders by groups $(P=0.799)$. The mean age of patients in travoprost $0.004 \%$ group included in the study was 66.6 years (SD \pm 15.8 years). The mean age of patients in fixed combination travoprost $0.004 \% /$ timolol $0.5 \%$ group was 63.8 years ( $\mathrm{SD} \pm 12.0$ years), with no statistically significant difference between the mean age by groups $(\mathrm{P}=0.443)$, (Table 1$)$.

Mean IOP at the first visit in the travoprost $0.004 \%$ group was 26.4 ( $\mathrm{SD} \pm 2.1$ ), and travoprost $0.004 \% /$ timolol $0.5 \%$ group was 26.3 ( $S D \pm 2.1$ ). There was no statistically significant difference in IOP of both eyes on first visit by groups $(\mathrm{P}>$ 0.05). In second visit, after three months on both groups we had decreased of intraocular pressure with no statistically significant difference between them. In third visit, after 6 months on right eye there was no statistically significant 
difference, while in left eye there was statistically significant difference in IOP (Diff. TOS 6/1 P $<0.001$ ). There were statistically significant difference in IOP in both eyes after third visit (after 1 year) and fourth visit (after 2 years), (Table 2 and Table 3).

Table 1. Patients demographics.

\begin{tabular}{cccc}
\hline & $\begin{array}{c}\text { Travoprost 0.004\% } \\
\text { group n }=31(62 \text { eyes) }\end{array}$ & $\begin{array}{c}\text { Travoprost 0.004\%/timolol 0.5\% } \\
\text { group n }=31(62 \text { eyes) }\end{array}$ & P-value \\
\hline Gender n (\%) & & & \\
Female & $14(45.2 \%)$ & $15(48.4 \%)$ & $\mathrm{P}=0.799$ \\
Male & $17(54.8 \%)$ & $16(51.6 \%)$ & \\
Age years (Mean $\pm \mathrm{SD})$ & $66.6 \pm 15.8$ & $63.8 \pm 12.0$ & $\mathrm{P}=0.443$ \\
\hline
\end{tabular}

Table 2. Mean IOP on the right eye.

\begin{tabular}{cccc}
\hline $\begin{array}{c}\text { Mean } \pm \text { SD } \\
\text { (mmHg) }\end{array}$ & $\begin{array}{c}\text { Travoprost } 0.004 \% \\
\text { group } \mathbf{n}=\mathbf{3 1}\end{array}$ & $\begin{array}{c}\text { Travoprost 0.004\%/timolol } \\
\text { 0.5\% group } \mathbf{n}=31\end{array}$ & P-value \\
\hline IOP (first visit) & $26.4 \pm 2.1$ & $26.3 \pm 2.1$ & $\mathrm{P}=0.932$ \\
IOP (after 3 months) & $18.5 \pm 1.3$ & $17.7 \pm 1.6$ & $\mathrm{P}=0.137$ \\
Diff. IOP 3/1 & $-7.9 \pm 2.3$ & $-8.6 \pm 2.0$ & $\mathrm{P}=0.227$ \\
IOP (after 6 months) & $18.9 \pm 1.5$ & $18.2 \pm 1.3$ & $\mathrm{P}=0.054$ \\
Diff. IOP 6/1 & $-7.5 \pm 2.7$ & $-8.1 \pm 2.2$ & $\mathrm{P}=0.305$ \\
IOP (after 12 months) & $19.8 \pm 1.3$ & $18.3 \pm 1.2$ & $\mathrm{P}=0.000$ \\
Diff. IOP 12/1 & $-6.6 \pm 2.4$ & $-8.0 \pm 2.1$ & $\mathrm{P}=0.024$ \\
IOP (after 24 months) & $20.5 \pm 1.5$ & $18.5 \pm 1.5$ & $\mathrm{P}=0.000$ \\
Diff. IOP 24/1 & $-5.9 \pm 2.9$ & $-7.8 \pm 2.3$ & $\mathrm{P}=0.005$ \\
\hline
\end{tabular}

Abbreviations: IOP, intraocular pressure; Diff. IOP, difference between first intraocular pressure and next visit after 3, 6, 12, and 24 months; SD, standard deviation.

Table 3. Mean IOP on the left eye.

\begin{tabular}{cccc}
\hline $\begin{array}{c}\text { Mean } \pm \text { SD } \\
\text { (mmHg) }\end{array}$ & $\begin{array}{c}\text { Travoprost 0.004\% } \\
\text { group } \mathbf{n}=\mathbf{3 1}\end{array}$ & $\begin{array}{c}\text { Travoprost 0.004\%/timolol } \\
\text { 0.5\% group } \mathbf{n}=\mathbf{3 1}\end{array}$ & P-value \\
\hline IOP (first visit) & $26.4 \pm 2.1$ & $26.3 \pm 2.1$ & $\mathrm{P}=0.955$ \\
IOP (after 3 months) & $18.6 \pm 1.6$ & $17.8 \pm 1.4$ & $\mathrm{P}=0.132$ \\
Diff. IOP 3/1 & $-7.8 \pm 2.3$ & $-8.5 \pm 1.9$ & $\mathrm{P}=0.148$ \\
IOP (after 6 months) & $19.1 \pm 1.4$ & $18.1 \pm 1.2$ & $\mathrm{P}=0.010$ \\
Diff. IOP 6/1 & $-7.3 \pm 2.4$ & $-8.2 \pm 2.3$ & $\mathrm{P}=0.004$ \\
IOP (after 12 months) & $19.9 \pm 1.4$ & $18.2 \pm 1.4$ & $\mathrm{P}=0.000$ \\
Diff. IOP 12/1 & $-6.5 \pm 2.4$ & $-8.1 \pm 2.0$ & $\mathrm{P}=0.014$ \\
IOP (after 24 months) & $20.3 \pm 1.4$ & $18.7 \pm 1.7$ & $\mathrm{P}=0.000$ \\
Diff. IOP 24/1 & $-6.1 \pm 2.9$ & $-7.6 \pm 2.3$ & $\mathrm{P}=0.032$ \\
\hline
\end{tabular}

Abbreviations: IOP, intraocular pressure; Diff. IOP, difference between first intraocular pressure and next visit after 3, 6, 12, and 24 months; SD, standard deviation. 
Table 4. Adverse events related to the study drug.

\begin{tabular}{|c|c|c|c|c|}
\hline \multirow{2}{*}{ Adverse events } & \multicolumn{2}{|c|}{ Travoprost $0.004 \%$ group } & \multicolumn{2}{|c|}{$\begin{array}{c}\text { Travoprost } 0.004 \% / \text { timolol } \\
0.5 \% \text { group }\end{array}$} \\
\hline & $\mathrm{N}$ & $\%$ & $\mathbf{N}$ & $\%$ \\
\hline Number of patients & 31 & 100.0 & 31 & 100.0 \\
\hline Conjunctival hyperaemia & 5 & 16.1 & 6 & 19.4 \\
\hline Ocular discomfort & 1 & 3.2 & 3 & 9.7 \\
\hline Pruritus & 1 & 3.2 & 1 & 3.2 \\
\hline Dry-eye sensation & 1 & 3.2 & 1 & 3.2 \\
\hline Photophobia & - & - & 2 & 6.5 \\
\hline Foreign-body sensation & 1 & 3.2 & 1 & 3.2 \\
\hline Hair disorders & 1 & 3.2 & 2 & 6.5 \\
\hline Keratitis & - & - & 1 & 3.2 \\
\hline Blurred vision & - & - & - & - \\
\hline Eye lid disorders & 1 & 3.2 & - & - \\
\hline Headache & - & - & 1 & 3.2 \\
\hline Total nr of adverse events & & & & \\
\hline
\end{tabular}

As we have shown on Table 4, blurred vision didn't have any of the patients in both groups. With the largest number of adverse events distinguished travoprost $0.004 \% /$ timolol $0.5 \%$ group. In both groups, conjunctival hyperaemia has been more frequent, 5 cases in travoprost group and 6 cases in travoprost/timolol fixed combination group (Table 4).

\section{Discussion}

Prostaglandin analogs are today the most prescribed antiglaucoma monotherapy because of their pottent intraocular pressure reduction and good tolerability. $40 \%$ of patients treated for glaucoma are unable to achieve adequate control of intraocular pressure with monotherapy [5] and combination of several drugs are very common.

Several clinical studies that evaluate the clinical efficacy and safety of fixed combination travoprost $0.004 \% /$ timolol $0.5 \%$ have been completed and this combination is safe and stable [14] [15] [16]. The first of these by Barnebey [7] was a randomized, prospective, multicenter, double-masked, parallel group study of 263 patients with either open angle glaucoma or ocular hypertension. After a variable washout period during which all ocular hypotensive medications were held, the patients were randomized to receive either: daily (AM) fixedcombination travoprost/timolol with vehicle (placebo) in the evening, twice daily timolol or daily (PM) travoprost with vehicle (placebo) in the morning. They were treated for a total of 3 months while their intraocular pressures were monitored at nine different time periods. Results showed that fixed-combination travoprost/timolol lowered intraocular pressure 1.9 - $3.3 \mathrm{mmHg}$ more that ti- 
molol alone, and 0.9 - $2.4 \mathrm{mmHg}$ more than travoprost alone. The adverse event profile was similar among all three study arms. Intraocular pressure reduction from baseline ranged $32 \%$ - 38\% for the fixed-combination medication, compared with $29 \%$ - 32\% for travoprost alone and 25\% - 30\% for timolol alone. These results suggest that fixed-combination travoprost/timolol produced clinically relevant intraocular pressure reductions greater than either agent alone, whereas the incidence of adverse events was comparable.

The results of this study demonstrate that travoprost $0.004 \%$ can achieve good IOP control. Reductions in mean intraocular pressure from baseline up to $26.3 \%$ were observed in the current study. Intraocular pressure lowering effect of fixed combination travoprost $0.004 \% /$ timolol $0.5 \%$ was superior in comparison to monotherapy with travoprost $0.004 \%$, during 2 years period. Reduction of intraocular pressure after administration travoprost $0.004 \% /$ timolol $0.5 \%$ fixed combination therapy was $17.8 \pm 1.4$ after 3 month, $18.1 \pm 1.2$ after 6 month, 18.2 \pm 1.4 after 1 year and $18.7 \pm 1.7$ after 2 year of therapy.

In our previous report, we showed the efficacy of PGA/beta-blocker fixed combination compare to PGA and beta-blocker maleate monotherapy. In our study, the mean IOP after 1 year in the prostaglandin group was $19.8 \mathrm{mmHg}$ (SD $\pm 1.3 \mathrm{mmHg}$ ), in beta-blockers group was $21.3 \mathrm{mmHg}$ (SD $\pm 1.2 \mathrm{mmHg}$ ) and in prostaglandin/beta-blockers group was $18.4 \mathrm{mmHg}(\mathrm{SD} \pm 1.3 \mathrm{mmHg}$; range: 16.0 - $21.0 \mathrm{mmHg}$ ). With Kruskal-Wallis test, there was no statistically significant difference of IOP in both eyes by groups $(\mathrm{KW}=113.0, \mathrm{P}<0.0001)$. The mean difference of IOP after 1 year (from first visit) in the patients of prostaglandin group was $-6.8 \mathrm{mmHg}(\mathrm{SD} \pm 2.2$ ), in the patients of beta-blockers group was $-4.6 \mathrm{mmHg}(\mathrm{SD} \pm 1.8)$ and in the patients of prostaglandin/beta-blockers group was $-7.9 \mathrm{mmHg}(\mathrm{SD} \pm 1.9 \mathrm{mmHg}$ ). With Kruskal-Wallis test, there was statistically significant difference of IOP value in both eyes between first and seventh visit by groups ( $\mathrm{KW}=80.8, \mathrm{P}<0.0001)$ [17].

\section{Conclusion}

Well designed observational studies can identify clinically important differences among therapeutical options and provide data on drug effectiveness and safety [18]. In our study, intraocular pressure lowering effect of fixed combination travoprost $0.004 \% /$ timolol $0.5 \%$ was superior in comparison to monotherapy with travoprost $0.004 \%$, with statistically significant differences in mean intraocular pressure values after one and two years of therapy.

\section{Acknowledgements}

No financial support was received for this submission.

\section{References}

[1] Quigley, H.A. and Broman, A.T. (2006) The Number of People with Glaucoma Worldwide in 2010 and 2020. British Journal of Ophthalmology, 90, 262-267. https://doi.org/10.1136/bjo.2005.081224 
[2] Leske, M.C., Heijl, A., Hussein, M., et al. (2003) Factors for Glaucoma Progression and the Effect of Treatment: The Early Manifest Glaucoma Treatment Trial. Arch Ophthalmology, 121, 48-56. https://doi.org/10.1001/archopht.121.1.48

[3] Kingman, S. (2004) Glaucoma Is Second Leading Cause of Blindness Globally. Bulletin of the World Health Organization, 82, 887-888.

[4] LeBlanc, R.P., Saheb, N.E. and Krip, G. (2000) Timolol: Long-Term Canadian Multicentre Study. Canadian Journal of Ophthalmology, 130, 429-440.

[5] Kass, M.A., Heuer, D.K., Higginbotham, E.J., et al. (2002) The Ocular Hypertension Treatment Study: A Randomized Trial Determines that Topical Ocular Hypotensive Medication Delays or Prevents the Onset of Primary Open-Angle Glaucoma. Arch Ophthalmology, 120, 701-713. https://doi.org/10.1001/archopht.120.6.701

[6] Schwartz, K. and Budenz, D. (2004) Current Management of Glaucoma. Current Opinion in Ophthalmology, 15, 119-126. https://doi.org/10.1097/00055735-200404000-00011

[7] Barnebey, H.S., Orengo-Nania, S., Flowers, B.E., et al. (2005) The Safety and Efficacy of Travoprost $0.004 \%$ /Timolol $0.5 \%$ Fixed Combination Ophthalmic Solution. American Journal of Ophthalmology, 140, 1.e1-1.e8.

https://doi.org/10.1016/j.ajo.2005.02.043

[8] Netland, P.A., Landry, T., Sullivan, E.K., et al. (2001) Travoprost Compared with Latanoprost and Timolol in Patients with Open-Angle Glaucoma or Ocular Hypertension. American Journal of Ophthalmology, 132, 472-484.

https://doi.org/10.1016/S0002-9394(01)01177-1

[9] Heijl, A., Leske, M.C., Bengtsson, B., et al. (2002) Reduction of Intraocular Pressure and Glaucoma Progression: Results from the Early Manifest Glaucoma Trial. Arch Ophthalmology, 120, 1268-1279. https://doi.org/10.1001/archopht.120.10.1268

[10] Kass, M.A., Gordon, M.O., Gao, F., et al. (2010) Delaying Treatment of Ocular Hypertension: The Ocular Hypertension Treatment Study. Arch Ophthalmology, 128, 276-287. https://doi.org/10.1001/archophthalmol.2010.20

[11] Asrani, S., Zeimer, R., Wilensky, J., et al. (2000) Large Diurnal Fluctuations in Intraocular Pressure Are an Independent Risk Factor in Patients with Glaucoma. Journal of Glaucoma, 9, 134-142. https://doi.org/10.1097/00061198-200004000-00002

[12] Lee, P.P., Walt, J.W., Rosenblatt, L.C., et al. (2007) Association between Intraocular Pressure Variation and Glaucoma Progression: Data from a United States Chart Review. American Journal of Ophthalmology, 144, 901-907. https://doi.org/10.1016/j.ajo.2007.07.040

[13] Musch, D.C., Gillespie, B.W., Niziol, L.M., et al. (2011) Intraocular Pressure Control and Long-Term Visual Field Loss in the Collaborative Initial Glaucoma Treatment Study. Ophthalmology, 118, 1766-1773. https://doi.org/10.1016/j.ophtha.2011.01.047

[14] Scuman, J.S., Katz, G.J., Lewis, R.A., et al. (2005) Efficacy and Safety of a Fixed Combination of Travoprost $0.004 \%$ /Timolol 0.5\% Ophthalmic Solution Once Daily for Open-Angle Glaucoma or Ocular Hypertension. American Journal of Ophthalmology, 140, 242.

[15] Hommer, A. (2007) A Double-Masked, Randomized, Parallel Comparison of a Fixed Combination of Bimatoprost 0.03\%/Timolol 0.5\% with Non-Fixed Combination Use in Patients with Glaucoma or Ocular Hypertension. European Journal of Ophthalmology, 17, 53-62.

[16] Hughes, B.A., Bacharach, J., Craven, E.R., et al. (2005) A Three Month, Multicenter, Double-Masked, Study of the Safety and Efficacy of Travoprost $0.004 \% /$ Timolol 0.5\% Ophthalmic Solution Compared to Travoprost $0.004 \%$ Ophthalmic Solution 
and Timolol 0.5\% Dosed Concomitantly in Sublects with Open-Angle Glaucoma or Ocular Hypertension. Journal of Glaucoma, 14, 392-399.

https://doi.org/10.1097/01.ijg.0000176935.08392.14

[17] Hoxha, G., et al. (2013) Comparison of Prostaglandin Analogue, Beta-Blockers and Prostaglandin Analogue/Beta-Blockers Fixed Combination in Patients with Primary Open Angle Glaucoma. Spektrum der Augenheilkunde, 27, 239-244.

https://doi.org/10.1007/s00717-013-0189-y

[18] Silverman, S.L. (2009) From Randomized Controlled Trials to Observational Studies. The American Journal of Medicine, 122, 114-120.

https://doi.org/10.1016/j.amjmed.2008.09.030

Submit or recommend next manuscript to SCIRP and we will provide best service for you:

Accepting pre-submission inquiries through Email, Facebook, LinkedIn, Twitter, etc. A wide selection of journals (inclusive of 9 subjects, more than 200 journals)

Providing 24-hour high-quality service

User-friendly online submission system

Fair and swift peer-review system

Efficient typesetting and proofreading procedure

Display of the result of downloads and visits, as well as the number of cited articles

Maximum dissemination of your research work

Submit your manuscript at: http://papersubmission.scirp.org/

Or contact ojoph@scirp.org 